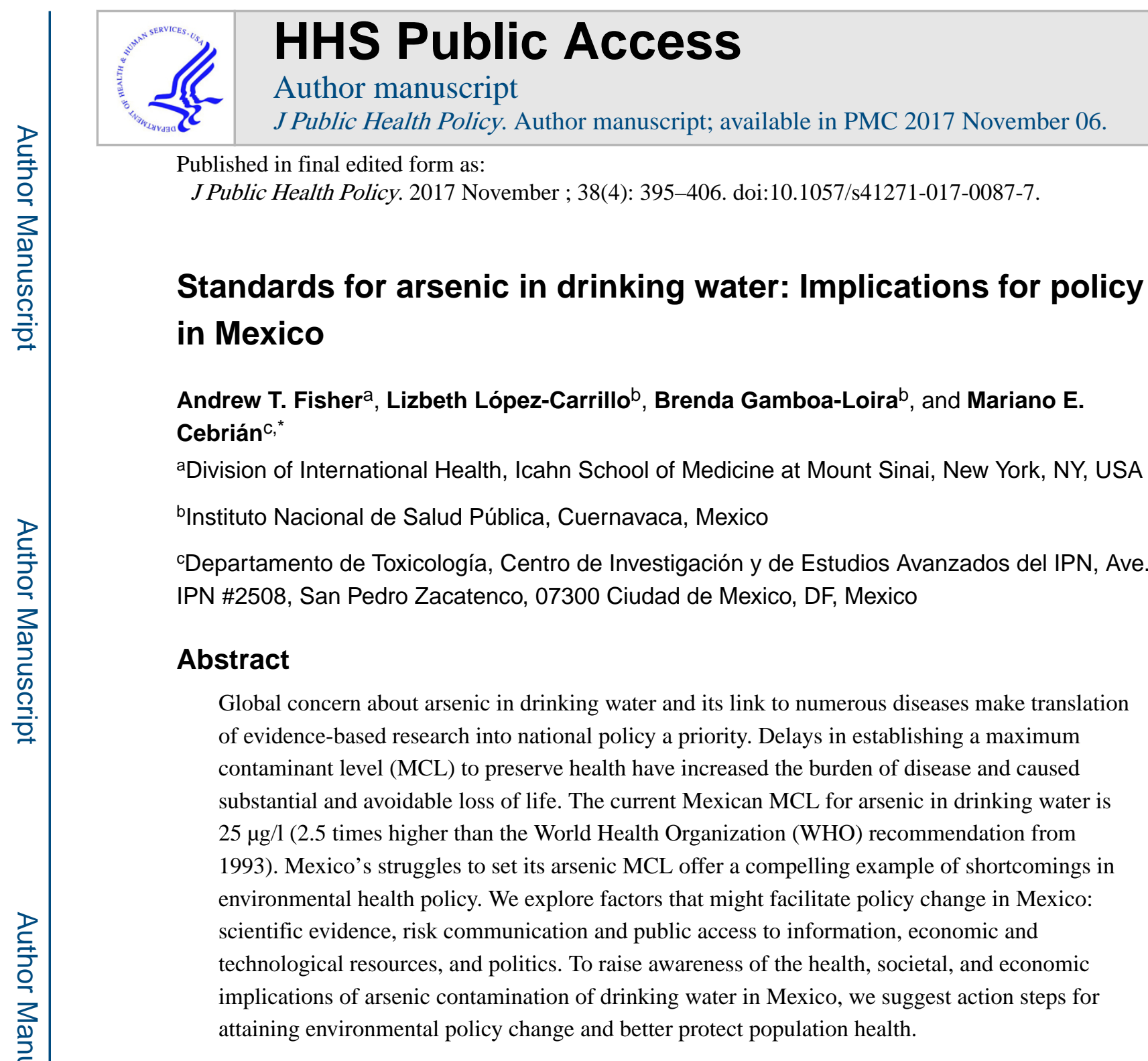

Keywords

arsenic; governance; drinking water; regulation; public health policy; Mexico

\title{
Introduction
}

Arsenic is an element widely distributed in the earth's crust that is released to the environment naturally and by human activity. Arsenic dissolves in waters, a process often enhanced by volcanic activity. Industrial activity adds arsenic to the environment: mining and smelting, petroleum refining, burning of fossil fuels (mainly coal), plus waste and wood incineraton. ${ }^{1}$

Epidemiological studies have shown associations between chronic exposure to arsenic and lung, skin, and bladder cancer. The International Agency for Research on Cancer (IARC) classifies arsenic a Group 1 carcinogen (carcinogenic to humans). ${ }^{2}$ Chronic exposure to

*Corresponding author: mcebrian@ cinvestav.mx. 
arsenic is also a risk factor for other chronic illnesses of the circulatory, nervous, endocrine, respiratory, and renal systems. ${ }^{1,2}$

Since 2010, arsenic contamination in drinking water has been one of the WHO's major global public health concerns, due to the large number of people exposed worldwide and arsenic's association with serious diseases. Limited data exist on the global burden of disease resulting from exposure to arsenic in drinking water. Most data have emerged from Bangladesh, where a 2004 study found the burden of lung, bladder, skin and kidney cancers, ischemic heart disease, and diabetes mellitus resulted in 9136 deaths in 1991 in a population of 86,832,738 plus 174,174 undiscounted disability-adjusted life years (DALYs) per year at concentrations greater than $50 \mu \mathrm{g}$ As/ $/ .^{3}$

In a 2012 study, also performed in Bangladesh, the authors estimated that 20 million people were exposed to concentrations above Bangladesh's national standard of $50 \mu \mathrm{g} / \mathrm{l}$. Forty-five million people were exposed to concentrations above the World Health Organization (WHO) guideline value of $10 \mu \mathrm{g} / \mathrm{l}$. Exposures above $50 \mu \mathrm{g} \mathrm{As} / \mathrm{l}$ and in the range of 10-50 $\mu \mathrm{g} \mathrm{As} / \mathrm{l}$ could, respectively, account for 24,000 and 19,000 adult deaths annually. ${ }^{4}$

International standards for arsenic in drinking water date back to 1958 when WHO first recommended a maximum contaminant level (MCL) of $200 \mu \mathrm{g} / \mathrm{l}$. As epidemiological evidence on chronic arsenic toxicity emerged, WHO lowered its standard twice, in 1963 to $50 \mu \mathrm{g} / \mathrm{l}$, and in 1993 to $10 \mu \mathrm{g} / 1 .{ }^{5}$ Several countries including the United States, Canada, Romania, Hungary, Taiwan, and Vietnam have adopted the latter WHO recommendation. Mexico, along with Argentina, Bolivia, and Peru, has delayed adopting this recommendation. ${ }^{6}$

To comply with these guidelines, countries where the economic 'footprints' are similar to Mexico's rely on arsenic detection methods and removal technologies developed, fieldtested, and used in South East Asia. ${ }^{7}$ Arsenic removal technologies include oxidation, coagulation-precipitation, absorption, plus ion exchange and membrane techniques. Chile has used coagulation for large-scale arsenic removal from both surface waters and ground water, declaring it a cost-effective way to meet the $10 \mu \mathrm{g} / \mathrm{l} \mathrm{MCL} .{ }^{8}$

In Mexico, researchers have since the 1950s documented arsenic concentrations in groundwater. ${ }^{9}$ The complex geology of Mexico (including igneous, sedimentary and metamorphic rocks, and active tectonic settings) facilitates 'natural' contamination of groundwater by arsenic. The source of arsenic contamination in northern Mexico remains under discussion. Several geochemical processes have been proposed: a hydrothermal system releasing high levels of lithium, boron, arsenic, and fluoride; the dissolution of iron and manganese oxides; and release arsenic retained in clays. This last may mobilize arsenic from the aquifer matrix into the groundwater. Scientists consider aquifer overexploitation and evaporation to be the primary mechanisms for enrichment of water with arsenic in Mexico. Other sources of release do not appear to play important roles. ${ }^{10}$

Levels reported for the northern states (Chihuahua, Coahuila, Durango, and Sonora) for arsenic in water range from 7 to $600 \mu \mathrm{g} / \mathrm{l}$. Nine other states (Aguascalientes, Guanajuato, Jalisco, Morelos, Oaxaca, Puebla, San Luis Potosi, Hidalgo, and Zacatecas) continue to 
report documented arsenic concentrations above the current Mexican MCL for drinking water. ${ }^{10,11}$ For the remaining Mexican states and/or populations exposed to levels above 10 $\mu \mathrm{g} / \mathrm{l}$, limited information exists. No one can estimate accurately number of people exposed nationally and the true burden of disease. In 2001, estimates based on a few states suggested a range from 400,000 to 2 million individuals exposed to concentrations above $25 \mu \mathrm{g} / \mathrm{l}^{12,13}$

Even though research on adverse health effects of arsenic in Mexico dates back decades, international journals published very few studies until the mid-1980s, when worldwide arsenic research gained momentum. Studies conducted in Mexico have shown that chronic exposure to arsenic in drinking water is associated with premalignant and malignant skin lesions, genotoxicity (higher frequencies of chromatid and chromosomal aberrations, aneuploidy, and micro-nucleated cells), impaired cognitive performance in school children (memory, problem solving, and attention, plus oppositional and hyperactive behavior), cardiovascular effects (increases in both carotid intima media thickness, an indicator of subclinical atherosclerotic burden, and plasma asymmetric dimethylarginine, a predictor of cardiovascular disease risk), diabetes, and breast cancer. ${ }^{13-20}$ Recent studies of pregnant women exposed to an average of $24.6 \mu \mathrm{g} / \mathrm{l}$ in drinking water have also revealed that urinary inorganic arsenic levels were associated with lower mean gestational age and newborn length, highlighting the risks associated with inorganic arsenic exposure in vulnerable populations. $^{21}$

We believe it is necessary to raise awareness of the health, societal, and economic implications of arsenic contamination in drinking water in Mexico, and to suggest action steps for an environmental policy change.

\section{Policy Background in Mexico}

Two federal institutions in Mexico, the National Water Commission (Comisión Nacional del Agua, CONAGUA) and the Federal Commission for Protection against Sanitary Risks (Comisión Federal para la Protección contra Riesgos Sanitarios, COFEPRIS), have primary responsibility for preventing harmful effects of environmental exposures. They share responsibility with entities at two other levels of government (state and municipal) for the management and preservation of water quality. ${ }^{22,23}$

The Mexican Constitution addresses protection of human health from the adverse effects of pollution through regulations called "Normas Oficiales Mexicanas" (or 'NOMs,' its acronym in Spanish). ${ }^{24} \mathrm{NOMs}$ spell out the characteristics and specifications applicable to products, processes, and activities that may constitute a risk to the environment. For pollutants, maximum permissible limits are specified. ${ }^{25}$

In 1994, Mexico adopted its first MCL for arsenic in drinking water (50 $\mu \mathrm{g} / \mathrm{l})(\mathrm{NOM} 127-$ SSA1-1994), eleven years after the WHO recommendation. ${ }^{26}$ In 2000, Mexico established a new MCL, which would be lowered by $5 \mu \mathrm{g} / \mathrm{l}$ each year from $50 \mu \mathrm{g} / \mathrm{l}$, to reach Mexico's current MCL of $25 \mu \mathrm{g} / \mathrm{l}$ in 2005 [NOM 127-SSA1-1994 (2000)]. This MCL remains 2.5 times higher than the current WHO recommendation (from 1993). ${ }^{27}$ In 2010, 17 years after 
the WHO recommendation, Mexico proposed a new NOM section for water quality regulation that included an MCL of $10 \mu \mathrm{gAs} / \mathrm{L}$ (NOM-000-SSA1-2010). ${ }^{28}$

To our knowledge, no public health advocacy focused on arsenic before 2014. In that year, a mine tailings spill from the Buenavista del Cobre mine contaminated the Sonora River in Northern Mexico. After this incident, Greenpeace advocated updating the NOM-127SSA1-1994-2000. The Mexican government released the 2010 draft NOM for public comment in 2014 (PROY NOM-250-SSA1-2014). ${ }^{29,30}$ As of this writing, advocacy has not resulted in expediting policy change; the government has not yet published a final version of the NOM.

\section{Policy Challenges}

Based on the literature and our own experience, several factors play major roles in facilitating environmental policy change in Mexico: (1) scientific evidence, (2) risk communication and public access to information, (3) economic resources, (4) technological resources, and (5) politics. We explore each element to understand its importance for advancing policy.

\section{Scientific evidence}

Mexico must increase its commitment to improving translation of scientific research to policy. Strengthening dialogue between policy-makers and the scientific community is important for policy and the policy-making process. Emerging international evidence suggests that chronic human exposure to arsenic at levels below $10 \mu \mathrm{g} / \mathrm{l}$ in drinking water is harmful to health. Studies published in scientific journals have, for example, shown increased risks of coronary heart disease and stroke mortality in Spanish municipalities. The association was strongest for women at arsenic levels between 1 and $10 \mu \mathrm{g} / \mathrm{l}^{31}$

United States (US) counties with average drinking water arsenic levels of $22.3 \mu \mathrm{g} / \mathrm{l}$ reported statistically significant increased risk of hospitalization for ischemic stroke compared to those with $4.5 \mu \mathrm{g} / \mathrm{l} .{ }^{32}$ Recent meta-analyses suggest that these $10 \mu \mathrm{g} / \mathrm{l}$ arsenic levels in drinking water may increase the risk of bladder cancer by at least 40 per cent. ${ }^{33}$ The large number of people exposed to such concentrations worldwide clearly means that the public health consequences of arsenic in drinking water are substantial.

In 2015, the US Environmental Protection Agency (EPA) was considering whether to lower the MCL to below $10 \mu \mathrm{g} / \mathrm{l} .{ }^{34}$ In Mexico, despite considerable local and international scientific evidence on the adverse effects of chronic arsenic exposure via drinking water, there has been no translation of this science to policy. Thus, we must increase policy makers' awareness of the maladies caused by arsenic in drinking water.

\section{Risk communication and public access to information}

Mexico needs more and better risk communication and public education. Mistaken perceptions that the risks are lower than science indicates mean that the exposed population has yet to demand better water quality or adopt personal risk reduction measures. We in 
Mexico can increase public awareness by reducing institutional barriers that constrain public access to information, including the scientific knowledge and supporting information. For example, the government requires an unnecessarily burdensome process when someone requests access to information. Can we organize the body of knowledge, prepare it in easily understood language for distribution to a lay audience, and disseminate it strategically? Only then, can the public health consequences be fully understood by the general public and its representatives - public health officials, regulators, policymakers, and legislators. This undertaking must engage members of the national academic community plus nongovernmental organizations. Efforts must target the media and classroom activities, especially in the affected areas.

\section{Economic resources}

Mexico's economy plays a pivotal role in the likelihood of improving environmental policy because mitigation efforts may be expensive. What will be the costs of a change from the current limit $(25 \mu \mathrm{g} / \mathrm{l})$ to a lower MCL? A cost/benefit analysis will be needed to compare the estimated cost of allowing arsenic contamination to continue versus the estimated costs of reducing it. Policy makers will need to know if the benefits outweigh the costs of mitigation. However, for a policymaker to support investment, this calculation alone will not suffice. To estimate the benefits of implementing a policy properly will also require calculating the sum of medical costs that reducing exposure would render unnecessary along with output productivity attained by decreasing arsenic exposure. We were unable to find information about previous cost-benefit analyses in Mexico for arsenic in drinking water in the publicly available literature. We reviewed academic journals and Diario Oficial de la Federación (Mexico), a source of government information comparable to what the United States publishes in its Federal Register. We assume that Mexico derives the basis for its current policy from WHO guidelines and/or regulations and studies performed in other countries. Mexico might try an alternative approach to analyzing costs and benefits, using methods employed to calculate Death and Disability-Adjusted Life Years (DALYs) for arsenic exposure in Bangladesh in 2001. ${ }^{3}$

\section{Technological resources}

Mexico needs to develop cost-effective technological resources for arsenic removal. The affordability and availability of arsenic removal systems plus monitoring and enforcing environmental policies have been a programmatic challenge for Mexican agencies.

Widespread exposure to arsenic in drinking water means Mexico needs to consider several strategies.

- Expansion of routine testing of water sources in urban and rural locations to ensure that interventions are targeted to areas where exposure has been confirmed, and monitoring and evaluation to assure that those interventions achieve sufficient reductions in arsenic exposure at a reasonable cost.

- $\quad$ Source substitution (often considered as a short-term solution at the state level) could be accomplished with limited resources, but it is not likely to be feasible for protecting many rural populations due to their isolation, poverty, and absence of alternative water sources. 
- Regulation of private wells needs to be considered because they are a common source of contaminated drinking water, particularly for many households and farms in central and northern Mexico. No special provision appears in the draft regulations.

Mexico will require long-term treatment strategies. The scientific and public health communities need to engage with populations at risk and with government to encourage use of new technologies for arsenic removal along with appropriate disposal of the removed arsenic.

\section{Politics}

Public health advocates in Mexico will need to engage in the political process to influence drinking water standards. Advocacy to add arsenic to the government's political agenda is the most likely way to influence current and near-future policy decisions. Who will conduct the risk assessments essential to strengthen evidence presented to policymakers?

In addition to the compelling health issues, Mexico has other incentives for giving priority to arsenic policy. The Organization for Economic Cooperation and Development (OECD) reviewed Mexico's environmental performance in 2013; that is, the extent to which Mexico's domestic objectives and international commitments are being met, based on environmental effectiveness and economic efficiency criteria. OECD recommended that the government strengthen environmental policy implementation by honoring its commitment to improve compliance with laws, regulations, and other expressions of public policy, such as guidelines. ${ }^{35}$ Mexico is the only country in North America not to adopt the $10 \mu \mathrm{g} / \mathrm{l} \mathrm{WHO}$ guideline: the US adopted it in 2001 with implementation required by 2006; and Canada in 2007. 5,36 Pressure to follow Mexico's northern neighbors could drive policy change.

Legal guidelines in Mexico, the NOMs, are supposed to be reviewed every 5 years - yet Mexico has not updated the arsenic in drinking water NOM since 2000, and the $2014 \mathrm{draft}$ has not yet reached NOM status.

We hope our analysis will help move regulation forward in a timely manner. If Mexico updates its arsenic policy to the current WHO recommendation, it might influence other countries to do so. National and international members of the academic community and nongovernmental organizations can play useful roles to alter policy in a manner that better protects the health of populations.

\section{Conclusion}

Delays in complying with the WHO-recommended arsenic MCL has undoubtedly led to an increased burden of disease and huge and avoidable loss of life. Mexico's current standard ( $25 \mu \mathrm{g} / \mathrm{l})$ does not safeguard human health, and thus reaching agreement to adopt the international standard, though not simple task, is critical. Policy change in Mexico cannot occur merely upon presentation of scientific evidence. Affordable arsenic removal technologies must be available. Alignment of political will with economic and institutional capacities plays a pivotal role. 
We believe that the WHO guideline value of $10 \mu \mathrm{g} / \mathrm{l}$ should be implemented in Mexico without delay, and in other countries with similar arsenic problems and economic and sociodemographic profiles. But even a rapid change in policy will not immediately reduce the incidence of arsenic-related disease, as past exposures are only now causing chronic disease - and the latent period means disease will occur long into the future.

Mexico needs to commit now to translation of evidence-based arsenic research into national policy — by reviewing, monitoring, and enforcing the NOM on arsenic in drinking water proposed in 2014.

\section{Acknowledgments}

This work was supported in part by Grant, MD 001452, from the National Center on Minority Health and Health Disparities of the US National Institutes of Health to the Mount Sinai International Exchange Program, Icahn School of Medicine in New York City, Dr. Luz Claudio, Principal Investigator.

\section{References}

1. Agency for Toxic Substances and Disease Registry. Toxicological Profile for Arsenic. Atlanta, GA: U.S. Department of Health and Human Services, Public Health Service; 2000.

2. International Agency for Research on Cancer. IARC monographs on the evaluation of carcinogenic risks to humans. Vol. 100C. Lyon, France: World Health Organization, International Agency for Research on Cancer; 2012. Arsenic, metals, fibres, and dusts.

3. Lokuge KM, Smith W, Caldwell B, Dear K, Milton AH. The effect of arsenic mitigation interventions on disease burden in Bangladesh. Environmental Health Perspectives. 2004; 112(11): 1172-1177. [PubMed: 15289162]

4. Flanagan SV, Johnston RB, Zheng Y. Arsenic in tube well water in Bangladesh: Health and economic impacts and implications for arsenic mitigation. Bulletin of the World Health Organization. 2012; 90(11):839-846. [PubMed: 23226896]

5. Smith AH, Lopipero PA, Bates MN, Steinmaus CM. Arsenic epidemiology and drinking water standards. Science. 2002; 296(5576):2145-2146. [PubMed: 12077388]

6. Ng JC, Wang J, Shraim A. A global health problem caused by arsenic from natural sources. Chemosphere. 2003; 52(9):1353-1359. [PubMed: 12867164]

7. Ahmed F, Minnatullah K, Talbi A. Arsenic Mitigation Technologies in South and East Asia. Arsenic Contamination of Groundwater in South and East Asian Countries. Vol II Technical Report. 2006:166-208.

8. Sancha AM, O’Ryan R. Managing Hazardous Pollutants in Chile: Arsenic. Reviews of Environmental Contamination and Toxicology. 2008; 196:123-146. [PubMed: 19025095]

9. Cebrián, ME., Albores, A., García-Vargas, G., Del Razo, LM., Ostrosky-Wegman, P. Chronic arsenic poisoning in humans. The case of Mexico. In: Nriagu, JO., editor. Arsenic in the Environment Part II: Human Health and Ecosystem Effects. New York: Wiley; 1994. p. 93-107.

10. Armienta MA, Segovia N. Arsenic and fluoride in the groundwater of Mexico. Environmental Geochemistry and Health. 2008; 30(4):345-353. [PubMed: 18335171]

11. Bundschuh J, Litter MI, Parvez F, Román-Ross G, Nicolli HB, Jean JS, et al. One century of arsenic exposure in Latin America: A review of history and occurrence from 14 countries. Science of the Total Environment. 2012; 429:2-35. [PubMed: 21959248]

12. Smedley PL, Kinniburgh DG. A review of the source, behaviour and distribution of arsenic in natural waters. Applied Geochemistry. 2002; 17:517-568.

13. Gonsebatt ME, Vega L, Salazar AM, Montero R, Guzmán P, Blas J, et al. Cytogenetic effects in human exposure to arsenic. Mutation Research. 1997; 386(3):219-228. [PubMed: 9219560]

14. Cebrián ME, Albores A, Aguilar A, Blakely E. Chronic arsenic poisoning in the North of Mexico. Human Toxicology. 1983; 2:121-133. [PubMed: 6840787] 
15. Méndez-Gómez J, García-Vargas GG, López-Carrillo L, Calderón-Aranda ES, Gómez A, Vera E, et al. Genotoxic effects of environmental exposure to arsenic and lead on children in Region Lagunera, Mexico. Annals of the New York Academy of Sciences. 2008; 1140:358-367. [PubMed: 18991935]

16. Rosado JL, Ronquillo D, Kordas K, Rojas O, Alatorre J, Lopez P, et al. Arsenic exposure and cognitive performance in Mexican Schoolchildren. Environmental Health Perspectives. 2007; 115(9):1371-1375. [PubMed: 17805430]

17. Osorio-Yáñez C, Ayllon-Vergara JC, Arreola-Mendoza L, Aguilar-Madrid G, HernándezCastellanos E, Sánchez-Peña LC, et al. Blood pressure, left ventricular geometry, and systolic function in children exposed to inorganic arsenic. Environmental Health Perspectives. 2015; 123(6):629-635. [PubMed: 25738397]

18. Osorio-Yáñez C, Ayllon-Vergara JC, Aguilar-Madrid G, Arreola-Mendoza L, HernándezCastellanos E, Barrera-Hernández A, et al. Carotid intima-media thickness and plasma asymmetric dimethylarginine in Mexican children exposed to inorganic arsenic. Environmental Health Perspectives. 2013; 121(9):1090-1096. [PubMed: 23757599]

19. Coronado-González JA, Del Razo LM, García-Vargas G, Sanmiguel-Salazar F, Escobedo-del a Peña J. Inorganic arsenic exposure and type 2 diabetes mellitus in Mexico. Environmental Research. 2014; 104(3):383-389.

20. López-Carrillo L, Hernández-Ramírez RU, Gandolfi AJ, Ornelas-Aguirre JM, Torres-Sánchez L, Cebrián ME. Arsenic methylation capacity is associated with breast cancer in northern Mexico. Toxicology and Applied Pharmacology. 2014; 280:53-59. [PubMed: 25062773]

21. Laine JE, Bailey KA, Rubio-Andrade M, Olshan AF, Smeester L, Drobná Z, et al. Maternal arsenic exposure, arsenic methylation efficiency, and birth outcomes in the Biomarkers of Exposure to ARsenic (BEAR) pregnancy cohort in Mexico. Environmental Health Perspectives. 2015; 123:186-192. [PubMed: 25325819]

22. Comisión Nacional del Agua. [accessed 29 November 2016] Objetivos y Estrategias. 2016. http:// www.gob.mx/cms/uploads/attachment/file/109732/OBJETIVOS_Y_ESTRAT_GIAS.pdf

23. Comisión Federal para la Protección contra Riesgos Sanitarios. [accessed 29 November 2016] Atribuciones, funciones y características de la COFEPRIS. 2015. http://www.cofepris.gob.mx/ cofepris/Paginas/AtribucionesFuncionesYCaracteristicas.aspx

24. Rowley A. Mexico's legal system of environmental protection. News \& Analysis. 1994; 24(8): 10431-10448.

25. Wolfson PS, Loyd ME, Carlsson CS, Hernandez MJ. Mexican environmental regulations: How they affect your business decisions. Natural Resources \& Environment. 1996; 10(4):48-51.

26. de Salud, Secretaría. Norma Oficial Mexicana NOM-127-SSA1-1994, Salud ambiental, agua para uso y consumo humano-Límites permisibles de calidad y tratamientos a que debe someterse el agua para su potabilización. México: Diario Oficial de la Federación; 1994.

27. Secretaría de Salud. Límites permisibles de calidad y tratamientos a que debe someterse el agua para su potabilización (Modificación del año. México: Diario Oficial de la Federación; 2000. Norma Oficial Mexicana NOM-127-SSA1-1994-2000 Salud ambiental, Agua para uso y consumo humano.

28. Secretaría de Salud. Límites máximos permisibles de la calidad del agua y requisitos sanitarios que deben cumplir los sistemas de abastecimiento de agua públicos y privados, su control y vigilancia. México: Diario Oficial de la Federación; 2010. PROYECTO de Norma Oficial Mexicana NOM-000-SSA1-2010, Agua para uso y consumo humano.

29. Greenpeace México. Ríos contaminados, ineficiencia y negligencia en México. 2014. Available at http://www.greenpeace.org/mexico/es/Noticias/2014/Septiembre/Rios-contaminados-ineficienciay-negligencia-en-Mexico/

30. Secretaría de Salud. Límites máximos permisibles de la calidad del agua y requisitos sanitarios que deben cumplir los sistemas de abastecimiento de agua públicos y privados, su control y vigilancia. México: Diario Oficial de la Federación; 2014. PROYECTO de Norma Oficial Mexicana PROY NOM-205-SSA1-2014, Agua para uso y consumo humano. 
31. Medrano MJ, Boix R, Pastor-Barriuso R, Palau M, Damián J, Ramis R, et al. Arsenic in public water supplies and cardiovascular mortality in Spain. Environmental Research. 2010; 110(5):448454. [PubMed: 19880104]

32. Lisabeth LD, Ahn HJ, Chen JJ, Sealy-Jefferson S, Burke JF, Meliker JR. Arsenic in drinking water and stroke hospitalizations in Michigan. Stroke. 2010; 41(11):2499-2504. [PubMed: 20947858]

33. Saint-Jacques N, Parker L, Brown P, Dummer TJ. Arsenic in drinking water and urinary tract cancers: A systematic review of 30 years of epidemiological evidence. Environmental Health. 2014; 13:44. [PubMed: 24889821]

34. Begum M, Horowitz J, Hossain MI. Low-dose risk assessment for arsenic: A meta-analysis approach. Asia-Pacific Journal of Public Health. 2015; 27(2):20-35.

35. Organization for Economic Cooperation and Development. OECD Environmental Performance Reviews: Mexico. Paris, France: OECD Publishing; 2013.

36. Health Canada. Guidelines for Canadian Drinking Water Quality-Summary Table. Water and Air Quality Bureau, Healthy Environments and Consumer Safety Branch. Ottawa, Ontario: Health Canada; 2014.

\section{Biographies}

Andrew T. Fisher, MPH, MA is a fellow at the Centers for Disease Control and Prevention (CDC) in Atlanta, Georgia. During the preparation of this manuscript he was a visiting fellow at the National Institute of Public Health (Instituto Nacional de Salud Pública-known as INSP) in Cuernavaca, Mexico from the Mount Sinai International Exchange Program, Icahn School of Medicine in New York City, a program combining environmental health and international policy. a.fisher@med.miami.edu.

Lizbeth López-Carrillo, DrPH, is an Environmental Epidemiologist and Senior Researcher at INSP, Mexico. She is a founder of the doctoral program in environmental health at INSP. lizbeth@insp.mx.

Brenda Gamboa-Loira, MSc, is completing a doctorate in Environmental Health Sciences at INSP, Mexico focusing on arsenic metabolism and arsenic exposure. blgl.bio@gmail.com.

Mariano E. Cebrián, $\mathrm{PhD}$, founded the Department of Toxicology and its postgraduate degree programs at The Center for Research and Advanced Studies of the National Polytechnic Institute (known as Cinvestav) and has published widely on toxicology and environmental health. 